\title{
Impacts of decentralization: The French experience in a comparative perspective
}

\author{
Renate Reiter ${ }^{a, *}$, Stephan Grohs ${ }^{\mathrm{b}}$, Falk Ebinger ${ }^{\mathrm{c}}$, \\ Sabine Kuhlmann ${ }^{\text {and Jörg Bogumile }}$ \\ ${ }^{a}$ Faculty of Cultural and Social Sciences, Departement of Political Science, FernUniversität in \\ Hagen, Universitätsstr. 41/ESG, Hagen 58084, Germany. \\ E-mail: Renate.Reiter@Fernuni-hagen.de \\ ${ }^{\mathrm{b}}$ Department of Politics and Public Administration, Universität Konstanz, Universitätsstraße 10, \\ Konstanz D-78464, Germany. \\ E-mail: stephan.grohs@uni-konstanz.de \\ ${ }^{c}$ Faculty of Social Science, Chair Public Administration, Local \& Regional Politics, \\ Ruhr-Universität, Universitätsstr. 150, GC 05/704, Bochum 44801, Germany. \\ E-mail: falk.ebinger@rub.de \\ ${ }^{\mathrm{d}}$ German University of Administrative, Sciences Speyer, Chair of Comparative Public \\ Administration, Freiherr-vom-Stein-Str. 2, Speyer 67346, Germany. \\ E-mail: kuhlmann@dhv-speyer.de \\ ${ }^{\mathrm{e}}$ Faculty of Social Science, Professorship Public Administration, Local \& Regional Politics, \\ Ruhr-Universität, Universitätsstr. 150, GC 05/707, Bochum 44801, Germany. \\ E-mail: Joerg.bogumil@rub.de \\ ${ }^{*}$ Corresponding author.
}

\begin{abstract}
Shifts in competencies between levels of government fundamentally changed public policymaking not only in France - with its two 'Actes' of decentralization - but also in a similar vein in Germany and England. The effects of these reforms, however, have so far remained largely understudied. This analysis traces national decentralization strategies and compares their impacts on public service performance in person-related services. The results of the empirical case studies are astonishing, as the often considered unique French case seems to share substantial features with its neighbors: Local government performance is largely determined by the properties of the policy area under consideration the potential to reap synergies between relevant actors at place and the capacity to built up professional expertise at the local level turn out to be decisive factors for the 'success' of decentralization as a multi-level governance strategy.
\end{abstract}

Keywords: decentralization; public administration; local government; performance; multi-level governance; social policy 


\section{Introduction}

Within the context of academic discourse on the decentralization of public functions (Pollitt and Bouckaert, 2004; Denters and Rose, 2005; Pollitt, 2005; Ahmad and Brosio, 2008), the two 'Actes' of decentralization in France (1982-1983 and 2003-2004) are often described as far-ranging and specific approaches to the devolution of state functions (Thoenig, 2005; Cole, 2006; Le Lidec, 2007, p. 111; Kuhlmann, 2009a). From a policy-specific and impact-oriented comparative perspective, the exceptionality of the French case, however, becomes less clear. Besides the unquestionable differences in national decentralization strategies, important parallels between the French case and decentralization in other European countries can be drawn upon.

In general public administration theory, the hypothesized outcomes of national decentralization policies are twofold. First, they are expected to promote efficiency and effectiveness in the fulfillment of public tasks. Second, they are assumed to increase the democratic accountability of public services (Pollitt and Bouckaert, 2004, pp. 105-106; Lockwood, 2008, p. 33). Yet, as we have hardly any comparative empirical knowledge about the impact of decentralizations on public policymaking at its implementation stage, that is upon the different dimensions representing the performance of public service delivery (Wollmann and Bouckaert, 2006), premature generalizations should be avoided. In this article, we address some of the most pressing puzzles of decentralization policies in France, Germany and England. The following questions will form the central part of the analysis: (1) What impact do decentralization policies have on the functional profile and performance of local government in the three countries? (2) What differences do dissimilar national decentralization strategies make? (3) Does the impact of decentralization vary in different public policy domains?

Relating to these questions, two basic hypothetical readings can be distinguished and shall be analyzed here for the three cases selected. The first, an institution-oriented perspective, focuses on the interior, that is local government and administration-related dimension of local public policymaking. One presumption is that a decentralization strategy, which strengthens the multi purposiveness of local responsibility, might increase the performance of local governments in some dimensions such as political accountability or to the cross-sectoral coordination (Wagener, 1976; Wollmann, 1997, 2004, 2008). Yet, as economies of scale decrease and political interference in administrative decision making rises, there is reason to suggest that efficiency and effectiveness might, in fact, decline, depending on the nature of the policy in question. Indeed, a decentralization-related move towards a single-purpose 
state administration might rather be seen as conducive to the efficiency and effectiveness record while simultaneously being associated with weak records on the dimensions of democratic control and horizontal coordination (Bogumil et al, 2004; Kuhlmann, 2006; Bauer et al, 2007; Ebinger and Bogumil, 2008). Our three cases, France, Germany and England, apply very different decentralization strategies and, thus, reflect three different paths of local institutional adjustment. As a consequence, we assume deviant results in the impact of national decentralization policies (Institutions matter-hypothesis).

Second, focusing on the dimension of local government as part of a system of multi-level governance from a policy-oriented perspective, it has been suggested that national decentralization policies will differ in their results from one functional field to another. Performance effects are supposedly dependent on the characteristics of the transferred functions and on the policy-specific decentralization strategies applied. These leave local actors with varying degrees of autonomy concerning public spending, decision making and the resolution of local interest conflicts (Lockwood, 2008, p. 34f.). Although the decentralization policies in our three cases diverge in scope and comprehensiveness of the transferred responsibilities, some cross-country similarities in decentralization can be expected (Policies matter-hypothesis)

In order to investigate these hypotheses, we draw on empirical findings from case studies on the decentralization of person- and community-related services in France, Germany and England (for details on the selected cases, see the 'Presentation of the cases' section). These countries have been selected as they represent typical cases of local government systems in Europe, with France representing the 'Southern' or 'Franco Group' type, Germany the 'North Middle European Group' type and England the 'Anglo Group' type of local government (Hesse and Sharpe, 1991, p. 606f.; Kuhlmann, 2006, 2008). The article is subdivided into three parts. First, we outline the conceptual and methodological framework for assessing the performance of local governments and develop five major performance dimensions. Second, we introduce the different decentralization strategies in France, Germany and England, since the beginning of the $1980 \mathrm{~s}$, by referring to two typologies commonly used by scholars of comparative public administration for the distinction of specific models of public administration and intergovernmental organization and of specific national decentralization strategies. Third, we present empirical findings from local case studies on the most recent steps of task devolution in France, Germany and England in the field of person- and community-related services. We analyze our findings according to the performance effects of national decentralization strategies in this last mentioned functional field and with regard to the hypothesis outlined. 


\section{Assessing Decentralization Strategies - Concept and Methods}

\section{Varieties of administrative organization and decentralization}

Since the beginning of the 1990s, numerous observers have stated a global trend towards the decentralization of public functions and services (Pollitt and Bouckaert, 2004; Denters and Rose, 2005). Against this background, scholars of comparative public administration have put forward one premise that shall serve as a starting point for our argument here. We assume that the performance of local government is a function of the specific organizational model underlying public administration and the intergovernmental setting in the respective state. Therefore, a shift in the organization of public administration and the intergovernmental setting as instigated by national decentralization reforms should accordingly lead to a change in the performance of local government (Pollitt and Bouckaert, 2004; Wollmann and Bouckaert, 2006).

For a classification of public administrative and intergovernmental organization, a multi-purpose model and a single-purpose model can be distinguished. According to Wollmann (2004), the primary criterion for the organization of public administration and intergovernmental relations based on the multi-purpose model is territoriality, whereas it is functionality when based on the single-purpose model. The multi-purpose model of local public administration, thus, refers to the (ideal) organizational case whereby local governments are charged with several inter-related or unrelated purposes. Territorial government in this case is based on a multi purposive or even universalistic functionality within a given territorially defined jurisdiction. The single-purpose model accordingly refers to the (ideal) organizational case whereby different types of administrative bodies are respectively charged with one main purpose (Wollmann and Bouckaert, 2006, pp. 12-14).

The three states under scrutiny here started from diverging origins and deployed different approaches to decentralization in respect of the rearrangement of central-local-relations over the past two decades (Kuhlmann, 2006). Following the literature on state and local government reform, national decentralization approaches can be classified into three ideal-typical forms of decentralization (Benz, 2002, pp. 209-214; Wollmann, 2004).

The first form, political decentralization, can be defined as the transfer of state functions that have either been located on the central level of government or its agencies, into the sphere of local government. Political decentralization means that locally legitimized bodies become competent to decide autonomously on the planning, financing and administration of their newly acquired executive functions. Compared to this rather far-reaching step, administrative decentralization marks a more moderate form of reordering intergovernmental relations. It is defined as the concession of executive functions from the state 
to local administrative authorities without the assignment of locally elected bodies to decide autonomously on the purpose. Acting as agents of national governments or governmental offices, local authorities remain at least formally under the states' full control not only for the legality but also for the functionality and the professional quality of the respective action (Wollmann, 1997, p. 106). Finally, administrative de-concentration is defined as the delegation of central state functions to administrative bodies on the sub-central level of government, which are hence still part of the states' own administration or dependent on it financially but not controlled directly. Subsumed is the delegation of central state functions of government agencies answerable to government bodies. In their place, functions are assigned to Quangos (Quasi-non-governmental Organizations, Skelcher, 1998).

\section{Dimensions and indicators of decentralization-related performance effects on local government}

How can the hypothesized effects of decentralization policies on the performance of local governments, as mentioned in the introduction, be approached in empirical research? In a first step, the different dimensions regarding the performance of local systems should be assessed.

To do so, we distinguish between five distinct performance dimensions (see Table 1), which relate to the three aspects of input legitimacy (democratic control and accountability, transparency), output legitimacy (efficiency and effectiveness of service delivery) and finally, the procedural aspects of coordination and steering. In addition, aspects of equity of service delivery between territorial entities are also included. For the deduction of performance indicators, we draw on comparative local government research (cf. Wollmann, 2004) and available evaluations of New Public Management (NPM)-style public sector reforms (cf. Pollitt and Bouckaert, 2004, pp. 103-142; Bogumil and Kuhlmann, 2006; Bogumil et al, 2007). Table 1 contains selected indicators for the measurement of changes in the defined performance dimensions. Besides available quantitative data, we also draw on case studies and the assessments of interviewed actors.

If we come back to the three types of decentralization developed in the 'Varieties of administrative organization and decentralization' section, we can presume differences in performance effects for each of the three decentralization strategies that can commonly be found in the relevant literature (cf. Pollitt, 2005). Table 2 summarizes the expected performance effects for the three decentralization strategies.

1. In the case of political decentralization, we can presume an increase democratic control and accountability and an increase in horizontal 
Table 1: Measurement of local government performance consecutive to national decentralization reforms

\begin{tabular}{|c|c|}
\hline $\begin{array}{l}\text { Dimensions of } \\
\text { performance }\end{array}$ & Performance indicators in different dimensions \\
\hline $\begin{array}{l}\text { Coordination } \\
\text { capability } \\
\text { (horizontal } \\
\text { and vertical) }\end{array}$ & $\begin{array}{l}\text { Horizontal coordination (internal dimension) } \\
\text { - Change in the degree of formalization of inter-service relations } \\
\text { - Change in the modes of inter-service coordination (for example, ad hoc } \\
\text { issue- and problem-oriented coordination; regular informal } \\
\text { coordination; regular meetings/rounds and so on) } \\
\text { - Change in the established conflict patterns on different subjects of } \\
\text { coordination- } \\
\text { Horizontal coordination (external dimension) } \\
\text { - Change in the general need for external coordination } \\
\text { - Change in the number of partnerships and the form and intensity of } \\
\text { interaction with external actors } \\
\text { - Intensity change in issue-/problem-oriented inter-communal } \\
\text { Vertical coordination (state-local government relation) } \\
\text { - Alteration in the form of coordination } \\
\text { - Alteration in the degree of coerciveness or voluntariness }\end{array}$ \\
\hline $\begin{array}{l}\text { Democratic } \\
\text { control of } \\
\text { decision } \\
\text { making/ } \\
\text { accountability }\end{array}$ & $\begin{array}{l}\text { Local council in charge of decision making and political control of } \\
\text { implementation of the new competence? } \\
\text { Integration of user groups/organised interests into local decision making? } \\
\text { Participation of citizens? } \\
\text { Transparency of decision making } \\
\text { Responsiveness }\end{array}$ \\
\hline Efficiency & $\begin{array}{l}\text { Changes in 'resource-input' (financial costs and personal)? } \\
\text { Changes in administrative output ('rate of public service production': } \\
\text { number of treated cases; duration of case-treatment) } \\
\text { Ratio of input-output }\end{array}$ \\
\hline Effectiveness & $\begin{array}{l}\text { Changes in: legal quality, formal correctness of public service production } \\
\text { Changes in the professional quality of public service production } \\
\text { Changes in the proximity to citizens: spatial closeness of administration, } \\
\text { electronic accessibility of administration } \\
\text { Cutback of vertical policy-merge? } \\
\text { Improvement of local capacity to decide and act autonomously }\end{array}$ \\
\hline $\begin{array}{l}\text { Degree of } \\
\text { trans-local } \\
\text { heterogeneity } \\
\text { in service } \\
\text { delivery }\end{array}$ & $\begin{array}{l}\text { Amplification of 'unequal' service fulfilment in an inter-communal } \\
\text { perspective, when starting from the states' claim to equal treatment } \\
\text { of all citizens? }\end{array}$ \\
\hline
\end{tabular}

Source: Author. 
Table 2: Expected performance: Effects of different types of decentralization

\begin{tabular}{lccc}
\hline $\begin{array}{l}\text { Dimensions of } \\
\text { performance }\end{array}$ & $\begin{array}{c}\text { Political } \\
\text { decentralization }\end{array}$ & $\begin{array}{c}\text { Administrative } \\
\text { decentralization }\end{array}$ & $\begin{array}{c}\text { De-concentration/horizontal } \\
\text { decentralization }\end{array}$ \\
\hline $\begin{array}{l}\text { Democratic control and } \\
\text { accountability }\end{array}$ & + & $\sim$ & - \\
$\begin{array}{l}\text { Horizontal coordination } \\
\text { Vertical coordination }\end{array}$ & + & + & - \\
Efficiency & - & - & + \\
Effectiveness & - & + & + \\
Heterogeneity & + & - & + \\
\hline
\end{tabular}

Source: Author.

coordination capacity, deducible from the multi-purpose model (Wollmann, 2008). These virtues go hand in hand with the downside of decreasing vertical coordination, effectiveness (because of underspecialization) and efficiency (because of decreasing economies of scale). With regard to the equity dimension, we can presume a growing heterogeneity between local governments.

2. In the case of administrative decentralization, we can expect only minor effects in the dimensions of democratic control and accountability and also with respect to horizontal and vertical coordination. Contrary to the case of political decentralization, when the state tries to implement decentralization reforms in order to save costs, advocates claim economies at the cost of the effectiveness of service delivery. As in the case of political decentralization, we can expect a growing heterogeneity because of the diverging capacities of service delivery.

3. De-concentration, finally, can be simply read as the opposite of political decentralization with decreasing democratic control and horizontal coordination, but improved vertical coordination, increasing efficiency and effectiveness because of specialization. Owing to similar capacities and procedural specifications, we can expect higher equity.

In the following section, before going into details of the empirical case studies, the specific pathways of France, Germany and England to decentralization shall be outlined.

\section{Pathways to Decentralization in France, Germany and England}

The cases of France, Germany and England, with their specific pathways to decentralization, represent, roughly, one of the three forms. As such, our 
premise that decentralization in France does not necessarily indicate French exceptionality should be regarded in light of the methods by which decentralization was carried out. As we shall see, the impact of the French policies shares many similarities with those in the other two countries.

\section{Political decentralization in France}

Owing to its unitary character, anchored in the Jacobine state tradition (Peters, 2008), France has been depicted as an example of a highly centralized model of public administration with local authorities being in a rather weak position (Hoffmann-Martinot, 2006, pp. 231-232). Before decentralization, the states' dominance was only 'tamed' (Mabileau, 1996, p. 25) by the established practice of multiple office holding (Cumul des mandats), giving local office holders a strong influence on national public policymaking. Given this initial position of an already informally decentralized state, some scholars have questioned the common assumption that 'Acte I' of the French decentralization reforms (1982-1983) had prompted a 'system change' (Thoenig, 2005; Kuhlmann, $2009 \mathrm{~b}$, p. 263). This is in spite of the abolishment of the states', that is, the prefects', right to comprehensive ex-ante control of local government action (Tutelle) and a huge transfer of competencies and resources from the state to the local authorities (regions, départements, municipalities) in the course of 'Acte I'. Anyhow, it was already during this first step of decentralization that the traditionally single purposive setting of public administration moved towards a more coordination-oriented and multi-purposive form of territorial government (Le Lidec, 2007; Kuhlmann, 2008, 2009a, c).

During the second round of decentralization in 2003-2004 ('Acte II'), the installation of such a form of territorial government continued (Thoenig, 2005). This time, especially the départements benefited from this new initiative of the central government to create a truly 'decentralized Republic'. They were given new competencies and resources in the field of social policy. Namely the départments became fully competent for the implementation of the social help regime for the unemployed, the RMI (Revenu minimum d'insertion). ${ }^{1}$

At the actual stage, the intergovernmental setting of the French state and public administration is characterized by high complexity (Kuhlmann, 2009b). It is as well marked by a strengthened autonomy of local governments, since 1981, (Cole, 2006) as well as by a high degree of vertical integration between levels of government in different functional fields.

Considering this empirical knowledge, the 'institutions matter' hypothesis formulated above, applies to France as follows: Political decentralization (in conjunction with the effects of inter-communalization; Deffigier, 2007) should make cross-policy coordination more viable and should strengthen 
accountability for policy outcomes. Yet, as decentralization, inter-communalization, and administrative de-concentration are set in place simultaneously, these positive effects could remain limited. Given the complexity of coordination between actors on the local level, the overall efficiency and effectiveness of the system would suffer and be weighed down by transaction costs (Kuhlmann, 2009a).

\section{Administrative decentralization in Germany}

Germany has a tradition of a politically and functionally strong, multi-purpose local government. The local level developed into a residual administration, delivering to local citizens functions that are not administered by higher levels. Local functions and tasks must be split into those that can be derived from the autonomous rights granted to the local level and those duties delegated to them merely for execution by the states (Länder). At the turn of the last century, the traditional portfolio of local tasks underwent an enlargement. Faced with immense financial pressures, most states plan or have already implemented far-reaching administrative reforms. Forerunners, such as Baden-Württemberg or Lower Saxony, dissolved hundreds of state agencies and changed their entire administrative setup (cf. Bogumil and Ebinger, 2008). One trait of these reforms was the delegation of considerable packages of administrative responsibilities on the local level while maintaining political decision making and control in the hands of the state. The intention behind this step was to empower the municipalities and reduce costs by shifting financial responsibility to the local level. Following its success, at least seen politically, a new wave of reforms imitating this approach currently sweeps over Germany (Bogumil and Ebinger, 2008, p. 284). Rather than progress being seen with the municipalities at the lower tier of local government, the county level held the most benefits from the transfer of tasks. The specific form or type of transfer here is one of administrative decentralization; the local or county councils still remain excluded from decision making.

In light of this empirical knowledge, the basic hypotheses formulated above should translate into a German context as follows: The modification of administrative structures and functional reforms on the Länder level supposedly strengthens the multi-purpose model of territorial organization and leads to greater comprehensive responsibilities on the local level. Consequently, mutually disruptive functions of state and local entities could be harmonized and cross-sectoral services might become better integrated. Simultaneously, some losses in the quality, effectiveness and efficiency in the execution of tasks should be expected because of declining specialization and routine of the workforce and augmented political interference. Nevertheless, only a limited 
increase in local democratic accountability can be expected for two reasons. First, many of the new responsibilities hardly interfere with the daily necessities of citizens but are complex administrative tasks. Second, as competencies are mostly transferred in the form of an administrative decentralization, the decision-making competencies of local councils are very limited.

\section{Administrative de-concentration in England}

England's reform record differs substantially from that of the continental European countries regarding the central-local nexus. Contrary to the continental trend of decentralization, it can be observed that there has been an ongoing weakening of local governments' functional profile as well as a tightening of supervision, regulation and intervention by the central government since the beginning of the early 1980s. The formerly strong and multifunctional localities in England were object of a blatant anti-local policy of the conservative governments. Local governments were considerably weakened in their functional profile not only by financial constraints but also by compulsory competitive tendering, which exposed traditional local tasks to market forces. Equally menacing to local government was the option granted to certain institutions to opt out of local control into quasi-autonomous bodies (or 'quangos') that were financially dependent on the central government (for example, grant-maintained schools, Housing Associations and so on). In addition, in certain fields, 'agencies', as dispersed parts of the central government's administrative apparatus, were installed at the local level, displacing the traditional local government. Finally, the conservative government imposed a tight control regime on the local governments by audits and performance targets (cf. Stoker, 2004; Wilson and Game, 2006). With regard to the identified types of decentralization, the English way can be considered as that of de-concentration or perhaps better 'horizontal decentralization' (Pollitt, 2005, p. 376). The change in government to New Labor did not change these policies in their substance, but added certain new features that can be subsumed under the headers of democratic renewal, joined-up governance and performance management (cf. Stoker, 2004; Wilson and Game, 2006). Recapitulating the English case, we can observe a general centralizing trend since the $1980 \mathrm{~s}$. We can identify a trajectory from a strong multi-purpose model to an increasingly single-purpose model.

On the basis of this empirical knowledge, the basic hypotheses formulated above should translate into the English context as follows: The sectoralization and fragmentation of administration is growing with the advance of local mono-functional agencies and quangos. If the hypotheses' assumptions are correct, this is likely to do a considerable damage to inter-sectoral 
coordination. Although functional performance might improve in individual sectors, transparency of decision-making processes, accountability and control would likely diminish.

\section{Selected Case Study Results}

In order to analyze the effects of decentralization, we carried out two local case studies in each of our three country cases under scrutiny between 2008 and 2009. We used a combined methodology of intensive secondary and document analysis and interviews with experts from local authorities. Following our general idea that different policies and their respective administrative tasks make a difference with regard to the performance effects of decentralization, we conducted the local case studies in different policy fields, namely in fields standing for 'paradigmatic' shifts between the central and local levels of government. As our second idea was to select cases subject to fairly recent and substantial changes, the selection of exactly the same public tasks was inhibited. We therefore concentrated on the analysis of the paradigmatic cases of task devolution in similar functional fields, standing for the general trend in the respective countries. As a general rule, in each country, we analyzed the decentralization of state functions in one person- or community-centered policy field (social help policy/RMI (F), integration services $(\mathrm{G})$, schools (E)) and in one 'technical' field concerning the regulation of interactions between the (local) state and different corporate interest actors (environment/trade control $(\mathrm{G})$, town and spatial planning $(\mathrm{F}, \mathrm{E})$ ).

In what follows, we concentrate on the presentation of empirical evidence from person- or community-related functions.

\section{Presentation of the cases}

In France, we selected two big départements located in the North and Southwest. At the time of investigation, both cases were characterized by a middle-range quota of unemployment as compared to the national average and a rather well-balanced public budget. The northern départment counts a high number of beneficiaries of the RMI ('RMIst'), in the southwestern case the number was rather, average. Both départements faced specific challenges of economic restructuring. In January 2004, during the 'Acte II' of the decentralization, both cases, such as all French départments, completely took over the administrative and financial responsibilities for the social help regime of the RMI from the state. By the time of the creation of the RMI in 1988, the French legislator had subdivided the RMI-related implementation 
tasks into a individual-related transfer-section and a group-related integration policy-section. Against this background, policy implementation had been based on an interwoven system of divided responsibility for the competencies within the individual-related policy-section (including the financial competency) held by the states' representative, the Prefet, and the group-related policy-section held by the elected council of the département, the Conseil général. Keeping this division of responsibilities in mind, the complete transfer of all RMI-related functions, first and foremost, meant that the budgets of the 100 French départements increased by a total of approximately 4.7 billion euros (in the two selected cases: 147 and 149 million euros or about 10 per cent of both départements' annual budget). Given the fact that the transfer of the RMI was largely organized in the form of a political decentralization, this redistribution of fiscal responsibility could already be expected to imply massive changes in the départements' practice of public policymaking. The decentralization reform was coupled with a change of the policy content and the instrumentation of social help policy. A new instrument, the so-called CI-RMA (Contrat d'insertion-Revenu minimum d'activité), was created with the aim of accelerating the labour market integration of the beneficiaries.

In Germany, case studies were conducted in Baden-Württemberg with relevant stakeholders on the Länder-level and in one of the biggest and most densely populated counties ( $>500000$ inhabitants). The county under scrutiny is splendidly institutionalized with a thriving economy and low fiscal pressures. Its bureaucracy counting 1500 employees disposes of significant resources. One of the main characteristics of the decentralization reform here was a massive increase in the counties' administrative responsibilities. The number of employees rose on average by approximately $40-50$ per cent. Hence, despite this major shift in administrative responsibility, almost no political decentralization was undertaken. The function assessed here is the social policy subsection dealing with integration services for the disabled (Eingliederungshilfe). It takes a special position in the bundle of transferred tasks: Before formal and political decentralization, this function was executed by two communally controlled agencies operating throughout the state. During the reform, close to all operative functions were transferred to the counties. As the integration services for the disabled burdens the cumulated budget of local governments in Baden-Württemberg with about 1.1 billion euros per annum, pressure from interest groups that is activists for the rights and opportunities of disabled citizens and care businesses exert increased pressure on local governments that find themselves bound to make stricter efforts in controlling costs.

One major example of the weakening of the role of local government in England in the process of 'quangoisation', a process identified as a major shift in the functional profiles of English local governments, is in the field of 
education that is traditionally safeguarded by the local governments. Here two case studies were conducted in two counties of medium size in the Northwest, respectively, Southwest of England. There is a certain variance in the economic situation; the southwestern case is rather well situated and rural, the northwestern county suffers structural weaknesses with higher numbers of unemployment and restricted local budgets. The field of state schools showed a rather typical reform record since the late 1980s. In 1988, the individual schools (previously under the umbrella of local government) were granted the right to opt out of local government and become self-governed bodies. At the same time, national curricula and a central system of benchmarking (league tables) were introduced to boost transparency and hence foster competition between schools by parental choice and open enrolment (cf. Pollitt et al, 1998). Labors' policy reintegrated these 'Grant-Maintained schools' as 'Foundation Schools' in the local authorities formally, but strengthened school autonomy further, so that the differences between the two models diminished. For scholars, this, nevertheless, opens up the possibility for a direct comparison of two administrative models of school governance, which can be characterized as examples of 'horizontal decentralization'.

In the following section, the encountered results are presented. To facilitate comparison, the effects of decentralization in the three country cases are presented one after the other in each of the five dimensions.

\section{Mapping performance changes}

\section{Horizontal and vertical coordination}

In the French case, the decentralization of the RMI-related public functions entailed a shortfall of intensive vertical coordination between the départments and the state. This could have made inner-départemental coordination between the Conseil général and other local interest holders of the RMI-policy 'easier'. Yet, the retreat of the state entailed new challenges of inner-départemental coordination both on its vertical and on its horizontal scale.

On the vertical scale, problems of coordination arose from the fact that the French legislator, when declaring the Conseil généraux the 'chefs de file' of the RMI-implementation, failed to regulate the relationship between the départements and their local implementation 'partners'. As French communal law does not state a formal hierarchy between the different types of local governments, this meant that notably the other territorial governments involved in the implementation are formally coequal to the Conseil général. Normally, they are tied to the départment on a contract basis. Not only in the two cases studied here but also in other départements (cf. IGAS, 2007), local office holders reported of coordination problems especially with the municipal 
partners of the Conseil général. In one of our two case studies, some actors went as far as to interpret the retreat of the state as the retreat of a 'neutral arbiter' and not as the retreat of a 'hierarchic watch dog' (Département 1, Executive officer Anti-Social Exclusion Service, 26 June 2008).

On the horizontal scale of coordination, the need for an advanced skill to complexity management came to the fore as a general problem. French RMI-policy encompassed a coordination-intensive case management approach already before the decentralization reform. Yet, with the states' retreat, it was now the full duty of the Conseil général to manage coordination with the wide range of different public and private local service providers. In one of the two cases, under scrutiny, where coordination had traditionally been based on a 'corporatist' relationship between the guarantor of RMI-related functions and the service providers, this was seen as an excessive demand on the local bureaucracies (Département 1, Director of Anti-Social Exclusion Service, 25 June 2008). Yet in the other, where the Conseil général chose a 'marketization' of service production and 'economization' of coordination, the management of complexity proved to function well (Département 2, Director of Social Integration Service, 28 October 2008).

Besides, the complete takeover of the RMI tasks by the départments also increased the need for inner-administrative horizontal coordination. In this context, the different Conseil généraux typically reacted either with a strategy of inner-départemental centralization or with a strategy of a stronger inner-départemental decentralization (IGAS, 2007). All in all, decentralization did show rather problematic effects regarding the capacity of the Conseil généraux to institute vertical coordination but led to more positive effects regarding the capacity for horizontal coordination.

Decentralization of integration services in Germany/Baden-Württemberg allowed, for the first time, a bundling of many social services onto one level. In the case at hand, interfaces with school authorities, public health department or youth welfare office were smoothed over as cost ownership was no longer a prominent issue and some merits of face to face contact between bureaucrats and local actors took effect. Furthermore, more comprehensive case management became possible as the county furnished additional personnel. Quality of service increased as the case managers' knowledge of local service providers improved beyond the level of the prior centralized service provision (County 1, Head of Department; Executive officers of Integration Service, 17 March 2008). On the downside, interviewees reported a dramatic increase in the need for horizontal coordination between the 44 local entities as a consequence of decentralization. As counties now have to react to legal changes or newly arising professional questions on their own, they are forced to harmonize their decisions ex post via several institutionalized inter-municipal meeting rounds at substantial interaction costs. The much 
downsized joint facility of the local level, the so-called Kommunalverband Jugend und Soziales (KVJS), would, to a certain degree, be the competent entity to relieve the cities and counties in some respects. However, it still acts as a precious provider of knowledge for the counties in the context of the knowledge-intense professional assessment of the disabled persons' needs (County 1, Head of Department, 17 March 2008; KVJS, Directorate, 2 October 2009). Summing up, decentralization shows some shortcomings, hence can be characterized as a positive sum game concerning the actors' capability to coordinate.

In the English case, the existing evidence shows clear deficits regarding the horizontal coordination as an effect of horizontal de-concentration. Between the schools, as well as between local government and schools, a weakening of cooperation and diminishing planning capacities can be observed. The weakening of coordination with local authorities in crosscutting issues, especially in fields like youth welfare, crime prevention, planning, leisure or sports facilities is reported regularly (County 1, Head of Services Area Education Office, 24 September 2009; County 2, Director for Children's Services, 14 October 2009). In the cases under scrutiny here, especially in the rural county, deficiencies occurred in organizing public transport for pupils (County 2, Headmaster Secondary School, 15 October 2009). With diminishing planning capacity, the schools compete for personnel instead of cooperating and exchanging teachers in certain subjects. The same counts for common goods, such as rooms, sports facilities or food provision, that can be shared for mutual use. As a counter move, vertical coordination was strengthened through national curricula, league tables and state-led inspectorates Office for Standards in Education (OFSTED). The effects of these measures are rather disputed. Gains in transparency go hand in hand with withdrawals regarding administrative costs and 'gaming' (cf. Hood, 2006) behaviour by individual schools. These negative findings were triggers of some reforms with the aim of promoting better coordination with other services (integration of educational services with child care and so on). At the time of research, these reforms struggled with hindrances and different 'administrative cultures' between the now integrated services (County 2, Director for Children's Services, 14 October 2009).

\section{Democratic control of decision making/accountability}

In the French case, the devolution of the RMI, first, went hand in hand with a formal effect, that is the formal increase in local democratic control and accountability. The Conseil général, now, was given full charge of decision making on RMI-policy planning. Furthermore, with the takeover of financial responsibility for the RMI by the départements, the Conseil général now has a strong interest in 'policy success' in the sense of a high policy output 
concomitant with low public spending and a high rate of (re-)integration of beneficiaries. This, in turn, not only placed départemental bureaucrats under pressure to integrate the relevant stakeholders of local public and private interests into the process of the départements' RMI-policy planning, but also placed politicians under a certain pressure to integrate the beneficiaries of the RMI - as voters and 'customers'. Yet, only in some cases were the latter effectively called to participate in policy planning. This was the Case, for example, in Département 2 under scrutiny here, where local authorities in charge of planning the départements' medium-term social integration programme for the implementation of the states' overall RMI-policy goals not only involved institutionalized stakeholders of interest (supporting organizations of policy measures; local firms and so on) but also representatives from the group of RMI beneficiaries into the planning process (Département Head of Social Inclusion Service, 29 October 2008). All in all, the decentralization-related formal strengthening of local representative democracy and political accountability was, only in some cases, followed by an increase in participatory democracy, whereas it more often turned out as a catalyst for the strengthening of the départemental executive (mayor; president of the general council).

In Germany/Baden-Württemberg, the chief executive of a county (Landrat) is only indirectly elected by the county council. Therefore, popular pressure mostly reflects (opposed) interests of particular municipalities rather than party politics (County 1, Head of Division, 18 March 2008). In addition, the services granted to disabled people on an individual level hardly ever generate advertency among the general public (County 1, Head of Department, 17 March 2008). Against this background, two effects were reported. First, the representation of disabled citizens has become easier, as responsible local politicians can be addressed directly or via local media. Second, the county councils' awareness of integration services increased significantly as its costs became a prominent but variable figure in the counties budget. Hence, the current and primary political interest lies in controlling this financial burden. As a consequence, the administrative apparatus was - at least temporarily supplied with additional resources, but at the same time was confronted with harsh fiscal objectives for the future.

In the English cases, the assessment remains ambivalent. On the one hand, there is a clear weakening of representative democratic control. On the other hand, a strengthening of democratic self-government and participation of the persons involved (especially parents) can be seen through more 'consumer' rights and 'market' transparency (cf. Pollitt et al, 1998). With schools becoming more autonomous, school boards, consisting of parents and representatives and local enterprises, gain stronger influence. An increase in parental choice and nationwide transparent benchmarking between schools (league tables and 
so on) can be considered a sign of a strengthened 'consumer democracy'. As a downsize, this consumer approach neglects the need for democratic legitimation surpassing the individual school (County 1, Head of Services Area Education Office, 24 September 2009) and reflects the deficiencies analyzed in the former paragraph. The introduction of area-based 'partnerships' that include multiple stakeholders in countywide governance arrangements, in the field of education and child care, are yet not capable to take in the role of the local authorities - at least in the interviewed local authorities (County 2, Director for Children's Services, 14 October 2009). As a consequence of this, a fragmentation of responsibilities and accountability is observable.

\section{Efficiency}

In France, the political decentralization of the RMI entailed a loss in cost efficiency. This, namely, was the result of two other developments going hand in hand with decentralization. First, decentralization accounted for a series of financial risks for the départments that, in sum, contributed to an increase in costs. In fact, the devolution of the RMI entailed the competence of the Conseil généraux to gather the transfers, which had wrongfully been paid to beneficiaries and which, for example, by 2008 alone amounted to a total of 120 million Euros (ODAS, 2009, p. 9). Yet, this competence turned out to be a 'cuckoo's egg' as the financial turnout collected from unlawfully paid transfers is known to be incalculable (Clerc, 2009). Besides, the départements now had to carry the total risk of variations in the number of beneficiaries. In order to prevent this risk from becoming too high at the outset, many départements and this was equally true in the two cases studied here - started to enforce stricter checks, as a form of 'abuse control', on individual beneficiaries. Often, they thereby managed to contain total spending. Yet, given the overall financial risk of abuse control, it remains unclear to date whether the départments can really hope for an economizing effect. At the same time, a second and important development led to an increase in costs. It resulted from the départements' eagerness to uphold high service quality after the takeover of the RMI. This, however, meant that transaction costs for knowledge inquiry, additional personnel, adjustment of internal management processes and technical support had to be met. In summary, the efficiency effects of decentralization suggest an increase, rather than reduction, in costs. This was, at least, the case in the two départments under scrutiny; here, in both cases, local bureaucrats reported on increasing costs for personnel and technical services (Département 1, Director of Anti-Social Exclusion Service, 25 June 2008; Département 2, Director of Social Integration Service, 28 October 2008).

Given the fact that counties in Germany/Baden-Württemberg took over the immediate financial responsibility for integration services, they have strong 
incentives to keep an eye on future costs. The suppression of the formerly centrally provided back-office services strains the decentralized units. Owing to an uneven distribution of qualified personnel between them, counties had to face rather different starting conditions as far as resources were concerned (cf. Ebinger and Bogumil, 2008). Last but not the least, the case management considered that the only way of slowing down the explosion of costs was by providing disabled citizens with tailor-made solutions as a first step. A high number of additional personnel had to be hired or qualified on the counties' expenses. In the meanwhile, these investments and a better coordination among services and facilitated processes reportedly increased efficiency to some extent (County 1, Head of Department, 17 March 2008). In sum, decentralization made meaningful investments in the field of integration services politically feasible. This could, in turn, lead to a substantial reduction in costs and an increase in service quality in the future.

In England, to the present day, efficiency gains remain disputable. The main part of the observable efficiency gains can be ascribed not to administrative changes but to new flexible budgets introduced in both local authority led and grant maintained schools (cf. Levacic, 1994). Indeed, there are indications of higher administrative costs introduced by the internalization of administrative functions (for example, personnel, building maintenance) and de-professionalization of administrative functions through self-government. As a headmaster told us, because of several reform movements, he wasn't able to give clear evidence on efficiency gains (County 1, Headmaster Secondary School 23 September 2009)

\section{Effectiveness}

In the French case, a decentralization-related effectiveness loss, indicated by a possible decrease in the legal and professional quality of local service production, could not be detected. Yet, these results become blurred when the effects of the RMI-policy reform are considered. This reform emerged parallel to the decentralization of the social help regime in 2003, instigated and decided upon by central government. After decentralization, as had been mentioned above, the départements were geared to keep the policy and service quality high and constant. This meant that many départements invested in the professionalization of their personnel. Yet the 'qualification offensive', which had been started by many Conseil généraux could not but yield its fruits with delay as local social workers not only had to learn new management skills and processrelated techniques but also had to acquaint themselves with new policy instruments. In addition, as under the former multi-level regime of the implementation of the RMI, the départements had already been in charge of the service-intensive integration policy-section of the RMI, the départemental 
bureaucracy already disposed of both the knowledge necessary for high-quality service production and of the contacts to a wide range of pertinent private local service providers to whom service delivery could be out-contracted. In this respect, quality deficits emerged as a consequence of the coordination failures mentioned above, which evolved subsequent to decentralization (Département 1, Executive officer Anti-Social Exclusion Service, 26 June 2008; cf. IGAS, 2007). Finally, many départements continued to closely cooperate with the local branches of states' services. The local level of government was thus able to benefit from the central state actors' technical and functional knowledge. Yet, the new orientation of the RMI-policy in the direction of an active employment policy entailed the necessity to reshape the already existing and often well-functioning partnerships. All in all, effectiveness did not decrease subsequent to decentralization. Although improvement seems possible, the duality of decentralization- and RMI-policy reform has often hindered the achievement of effectiveness gains.

The effectiveness of all decentralized competencies reportedly depends heavily on the strength of their position within the host administration. The case observed in Germany/Baden-Württemberg, in the field of integration services, was very favourably institutionalized and granted significant institutional autonomy. This setting allowed the management to establish the case-management approach on a broader basis and to tighten in-house and external relations with all actors involved in the support of disabled citizens. Closer multilateral cooperation reportedly improved control and helped refine the range of services offered by third-party providers. To compliment local competencies, the central KVJS is now called in on a case-by-case basis for specialized knowledge. This functional division of labour increased the use of ambulant and low-threshold services and raised the overall service quality substantially. However, the results from the presented showcase cannot be generalized uncritically. Experts and stakeholders report of high pressures exerted on case managers in many counties to cut costs by any means (Special Interest Group for Disabled People, Representative, 2 October 2009; Charity 1, Head, 30 September 2009; Charity 2, Division Head, 1 October 2009). The quality of the services offered to the disabled seems to be determined strongly by their - or their families' - possibility to voice and enforce their needs.

With regard to the English case, one interesting result is that no clear standardization of results has taken place which clearly runs counter to the aims of an increase in centralized control of school performance. Some improvements are reported regarding a more problem-driven allocation of schools' own resources because of school-based management. Differences between schools can be traced back to the social background of the area rather than to school governance (County 1, Head of Services Area Education Office, 24 September 2009). With regard to the dimension of successful integration of 
education and social work, there is a clear lack in goal attainment in the more autonomous schools. The 'partnership' approach wasn't able to cope with these deficiencies. In summary, there is little evidence, so far, for an increase in effectiveness that could be attributed to the de-concentration in the education sector.

\section{Heterogeneity of service production between local units}

In France, the decentralization of the RMI clearly contributed to an increase in the, already existing, trans-territorial heterogeneity of social public service production (cf. Mission parlementaire, 2009, p. 13). The decentralization of person-related functions revealed differences between the départements concerning the institutionalization and instrumentation of the RMI-related policymaking. Remarkable differences emerged especially between those départements with a well-balanced public budget and those under budgetary constraint, the latter reportedly not being able to afford an expansion of the départemental range of integration services to the 'RMIst' (Département 1, Director of Anti-Social Exclusion Service, 25 June 2008).

In the Germany/Baden-Württemberg case, different starting conditions between counties and the individual management philosophies of the mayors and county executives led to very different approaches in institutionalization, instruments and how the claims of entitled persons were dealt with. Although some executives installed integrated social affairs departments, others kept the new tasks separate from the existing administration. Most counties invested in building up capacities for case management, some did not. And, although the majority of counties are reportedly anxious to find a commonly acceptable balance between desirable services and budget constraints, a few aim to undercut costs. A lacking central legal and policy department further increased this heterogeneity. Nowadays, a multitude of coordinative meetings and commonly edited guidelines guarantees harmonization in '90 per cent of the issues' (County 1, Head of Department, 17 March 2008). To sum up, as strategies and instruments get harmonized, the cultural differences in the dealings with disabled citizens' needs remain between counties.

The heterogeneity between schools as well as between different local authorities has increased in the English case. From the view of reformers, this can be seen as an intended consequence of the horizontal decentralization approach. Against this approach, there is little evidence of an improvement of services through competition. On the contrary, this heterogeneity increases preexisting advantages in respect of disadvantages of single schools regarding to social background of the pupils, building maintenance and the recruitment of teachers. In both counties, these inequities occurred and are reported to be a major problem for building up community-wide strategies for the improvement of educational policies. 
Table 3: Performance effects in comparison

\begin{tabular}{|c|c|c|c|c|c|c|c|c|c|}
\hline & \multicolumn{3}{|c|}{ France } & \multicolumn{3}{|c|}{ Germany } & \multicolumn{3}{|c|}{ England $^{a}$} \\
\hline & \multicolumn{3}{|c|}{$\begin{array}{l}\text { Policy } 1(P D) \\
\text { Social assistance }\end{array}$} & \multicolumn{3}{|c|}{$\begin{array}{c}\text { Policy } 1(A D) \\
\text { Integration services }\end{array}$} & \multicolumn{3}{|c|}{$\begin{array}{c}\text { Policy } 1 \text { ( HD) } \\
\text { Schools }\end{array}$} \\
\hline & $\operatorname{Exp}$ & $C 1$ & $C 2$ & $\operatorname{Exp}$ & $C l$ & $C 2$ & $\operatorname{Exp}$ & Cl & $C 2$ \\
\hline Democratic control and accountability & + & + & + & - & $\sim$ & - & - & $+1-$ & - \\
\hline Horizontal coordination & + & $\sim$ & + & + & + & - & - & - & - \\
\hline Vertical coordination & - & - & $\sim$ & - & - & - & + & + & - \\
\hline Efficiency & - & - & - & + & + & - & + & $\sim$ & - \\
\hline Effectiveness & - & + & + & - & + & - & + & $\sim$ & - \\
\hline Heterogeneity & + & + & + & + & + & - & - & - & - \\
\hline
\end{tabular}

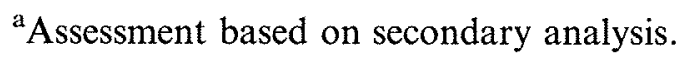

Note: $\operatorname{Exp}=$ Expected performance effect; $\mathrm{Cl}=$ Case 1; $\mathrm{C} 2=$ Case 2. "+Green" marks an agreement with the Performance Hypotheses, "-red" a deviance and " yellow" unclear effects. Source: Author.

\section{Conclusion}

The empirical analysis of decentralization reforms in France, Germany and England has allowed for a test of the analytical framework developed in this article to compare local government performance.

Drawing on the case studies and on the cross-country comparison, we can, first, observe in some dimensions rather clear confirmations for our country-specific hypotheses. Table 3 summarizes the findings based on expert interviews in the selected case municipalities and contrasts them with our expectations. With regard to the dimensions of political control and (vertical and horizontal) coordination, we found our assumptions most strongly confirmed. Hints for a weakening of political control and a loss in horizontal coordination could be found in the case of schools in England, whereas politicization and partly strengthened coordination capacities could be observed in France's RMI and the German integration services. With regard to the efficiency and effectiveness dimensions, clear-cut statements would not do justice to the inter-communal variance found in practice. And, finally, the hypothesized effect of decentralization on inter-local heterogeneity in service provision also found empirical basis. To put things straight here: growing heterogeneity does not refer to the variety of institutional forms deployed, but to the disparity of the services provided to citizens. Hence, with regard to all cases, it can be stated that the form of decentralization did influence the 'performance' of local governments. In all three cases, traditional national peculiarities and preexisting institutional arrangements structuring intergovernmental relations 
seemed to determine public sector modernization. Nevertheless, practice and results in the dealings with the transferred functions changed considerably. In fact, the 'institutions matter' hypothesis only explains part of the story.

The presented results show a significant function-bound impact on local government performance for all three country cases and most local entity cases. Despite country-specific forms of decentralization, the political saliency of tasks devolved, the possibility to effectuate synergies and the degree of professional expertise required locally, turn out to be decisive factors for the 'success' of decentralization as a multi-level governance strategy. With regard to the performance impact of decentralization, one can presume that in person-related policies with essential coordination exigencies, the gains in effectiveness might outweigh the losses because of de-specialization. This hints to a technical policy bias in the debate on performance effects and performance management so far.

Going beyond these findings and taking a wider perspective, we can observe that our, still rather, limited set of dimensions seems to cover the actual changes well. Only few residual dimensions seem unconsidered. Hence, it became apparent that decentralization as a specific kind of institutional policy, which can take on different forms, makes a difference as such, but that a combined view on institutional and policy reforms should be preferred for an evaluation of decentralization effects.

\section{Note}

1 The RMI has, meanwhile, been replaced by the newly created RSA (Revenu de solidarité active) in June 2009.

\section{References}

Ahmad, E. and Brosio, G. (2008) Handbook of Fiscal Federalism. Cheltenham, UK/Northampton, MA: Edward Elgar.

Bauer, M.W., Bogumil, J., Knill, Chr., Ebinger, F., Krapf, S. and Reißig, K. (2007) Modernisierung der Umweltverwaltung. Reformstrategien und Effekte in den Bundesländern. Berlin, Germany: Edition Sigma.

Benz, A. (2002) Die territoriale Dimension von Verwaltung. In: K. König (ed.) Deutsche Verwaltung an der Wende zum 21. Jahrhundert. Baden-Baden, Germany: Nomos, pp. 207-228.

Bogumil, J. and Ebinger, F. (2008) Verwaltungspolitik in den Bundesländern - Vom Stiefkind zum Darling der Politik. In: A. Hildebrandt and F. Wolf (eds.) Die Politik der Bundesländer. Politikfelder und Institutionenpolitik. Wiesbaden, Germany: VS, pp. 275-288.

Bogumil, J., Grohs, S., Kuhlmann, S. and Ohm, A. (2007) Zehn Jahre Neues Steuerungsmodell. Eine Bilanz kommunaler Verwaltungsmodernisierung. Berlin, Germany: Edition sigma. 
Bogumil, J. and Kuhlmann, S. (2006) Wirkungen lokaler Verwaltungsreformen: Möglichkeiten und Probleme der Performanzevaluation. In: W. Jann, M. Röber and H. Wollmann (eds.) Public Management. Grundlagen, Wirkung und Kritik. Berlin, Germany: Edition Sigma, pp. 349-371.

Bogumil, J., Reichard, Chr. and Siebart, P. (2004) Gutachten zur Verwaltungsstrukturreform in NRW. Schriftenreihe der Stiftung Westfalen-Initiative. Band 8. Ibbenbüren, Germany: Ibbenbürener.

Clerc, D. (2009) Décryptage de la loi du ler décembre 2008 (2e partie): Les measures relatives au revenu de solidarité active. La lettre de l'insertion no. 9 (Avril), http://www.lettre-insertion.fr/ newsletter-lettre-insertion-fr-avril-2009_fr_pub_832.html\#42684, accessed 4 October 2009.

Cole, A. (2006) Decentralization in France: Central steering, capacity building and identity construction. French Politics 4(1): 31-57.

Deffigier, C. (2007) Intercommunalité et Territorialisation de l'action publique en Europe. Revue française d'administration publique 121-122(1-2): 79-98.

Denters, B. and Rose, L. (eds.) (2005) Comparing Local Governance: Trends and Developments. New York: Palgrave Macmillan.

Ebinger, F. and Bogumil, J. (2008) Grenzen der Subsidiarität - Verwaltungsreform und Kommunalisierung in den Ländern. In: H. Heinelt and A. Vetter (eds.) Lokale Politikforschung heute. Wiesbaden, Germany: VS, pp. 165-196.

Hesse, J.J. and Sharpe, L.J. (1991) Local government in international perspective: Some comparative observations. In: J.J. Hesse (ed.) Local Government and Urban Affairs in International Perspective. Baden-Baden, Germany: Nomos, pp. 603-621.

Hoffmann-Martinot, V. (2006) Reform and modernization of urban government in France. In: V. Hoffmann-Martinot and H. Wollmann (eds.) State and Local Government Reforms in France and Germany. Divergence and Convergence. Wiesbaden, Germany: VS, pp. 231-251.

Hood, C. (2006) Gaming in targetworld: The targets approach to managing British Public Services. Public Administration Review 66(4): 515-520.

IGAS (Inspection générale des affaires sociales). (2007) Rapport sur la gestion du revenue minimum d'insertion (RMI). Présenté par Jean-François Chevallereaux, Michel Laroque, Marguerite Moleux et Isabelle Rougier. Rapport RM2007-165P, Novembre, http://lesrapports .ladocumentationfrancaise.fr/BRP/074000760/0000.pdf, accessed 6 Octobre 2009.

Kuhlmann, S. (2006) Local authorities between the state and the market: An international comparison of local government systems and reforms. German Journal of Urban Studies 45(2): 5-46.

Kuhlmann, S. (2008) Dezentralisierung in Frankreich: Ende der unteilbaren Republik? der moderne staat - dms 1(1): 201-220.

Kuhlmann, S. (2009a) Politik- und Verwaltungsreform in Kontinentaleuropa: Subnationaler Institutionenwandel im deutsch-französischen Vergleich. Baden-Baden, Germany: Nomos.

Kuhlmann, S. (2009b) Analyse comparative de la décentralisation en France et en Allemagne. Pouvoirs Locaux 81(2): 81-85.

Kuhlmann, S. (2009c) Frankreich: Wandlungen des jakobinischen Staates - 'faire mieux avec moins? In: Europäisches Zentrum für Föderalismus-Forschung Tübingen (ed.) Jahrbuch des Föderalismus 2009. Baden-Baden, Germany: Nomos, pp. 263-274.

Le Lidec, P. (2007) Le jeu du compromis: l'État et les collectivités territoriales dans la décentralisation en France. Revue française d'administration publique, no 121-122(1-2), pp. 111-130.

Levacic, R. (1994) Evaluating the Performance of Quasi-Markets in Education. In: W. Bartlett, C. Propper, D. Wilson and J. LeGrand (eds.) Quasi-Markets in the Welfare State. Bristol, UK: Saus Publications, pp. 35-55.

Lockwood, B. (2008) The political economy of decentralization. In: E. Ahmad and G. Brosio (eds.) Handbook of Fiscal Federalism. Cheltenham, UK/Northampton, MA: Edward Elgar, pp. 33-60. 
Mabileau, A. (1996) Kommunalpolitik und -verwaltung in Frankreich. Das 'lokale System' Frankreichs. Basel u.a., Switzerland: Birkhäuser.

Mission parlementaire sur les droits connexes dans le cadre de la généralisation du RSA. (2009) Rapport de Madame Sylvie Desmarescaux, Sénateur. Catherine Hesse, Membre de l'inspection générale des affaires sociales, Mai, http://lesrapports.ladocumentationfrancaise.fr/BRP/ 094000221/0000.pdf, accessed 8 Octobre 2009.

ODAS (Observatoire national de l'action sociale décentralisée). (2009) Dépenses départementales d'action sociale en 2008: la fin d'un cycle. La lettre de l'Odas (Finances départementales). 16 Juin, http://www.odas.net/IMG/pdf/Odas_lettre_de_1_Odas_des_finances_06_09_V7.pdf, accessed 8 Octobre 2009.

Peters, G. (2008) The Napoleonic tradition. International Journal of Public Sector Management 21(2): 118-132.

Pollitt, Chr. (2005) Decentralization. In: E. Ferlie, L.E. Lynn and C. Pollitt (eds.) The Oxford Handbook of Public Management. Oxford: OUP, pp. 371-397.

Pollitt, C., Birchall, J. and Putman, K. (1998) Decentralising Public Service Management. Houndsmills: Macmillan.

Pollitt, Chr. and Bouckaert, G. (2004) Public Management Reform: A Comparative Analysis, 2nd edn. Oxford: OUP.

Skelcher, C. (1998) The Appointed State: Quasi-Governmental Organizations and Democracy. Buckingham: Open University Press.

Stoker, G. (2004) Transforming Local Governance. From Thatcherism to New Labour. Houndmills: Palgrave.

Thoenig, J.-Cl. (2005) Territorial administration and political control: Decentralization in France. Public Administration 83(3): 685-708.

Wagener, F. (1976) Typen der verselbständigten Erfüllung öffentlicher Aufgaben. In: F. Wagener (ed.) Verselbständigung von Verwaltungsträgern. Bonn, Germany: Deutsche Sektion, pp. 31-51.

Wilson, D. and Game, Chr. (2006) Local Government in the United Kingdom, 4th edn. Houndsmills: Palgrave.

Wollmann, H. (1997) 'Echte Kommunalisierung' der Verwaltungsaufgaben: innovatives Leitbild für umfassende Funktionalreform? Landes- und Kommunalverwaltung (LKV) 7(4): 105-144.

Wollmann, H. (2004) Local government reforms in Great Britain, Sweden, Germany and France: Between multi-function and single purpose organisations. Local Government Studies 20(4): 639-665.

Wollmann, H. (2008) Reformen in Kommunalpolitik und -verwaltung. England, Schweden, Frankreich und Deutschland im Vergleich. Wiesbaden, Germany: VS.

Wollmann, H. and Bouckaert, G. (2006) State organisation in France and Germany between territoriality and functionality. In: V. Hoffmann-Martinot and H. Wollmann (eds.) State and Local Government Reforms in France and Germany. Divergence and Convergence. Wiesbaden, Germany: VS, pp. 11-37. 